(C) 2020, The Authors. Published by Elsevier Inc. and Fass Inc. on behalf of the American Dairy Science Association ${ }^{\circledR}$. This is an open access article under the CC BY-NC-ND license (http://creativecommons.org/licenses/by-nc-nd/4.0/).

\title{
Early supplementation of Saccharomyces cerevisiae boulardii CNCM I-1079 in newborn dairy calves increases IgA production in the intestine at 1 week of age
}

\author{
C. Villot, ${ }^{1,2} \odot$ Y. Chen, ${ }^{1,3}$ K. Pedgerachny, ${ }^{1} \odot$ F. Chaucheyras-Durand, ${ }^{2} \odot$ E. Chevaux, ${ }^{2} \odot$ A. Skidmore, ${ }^{4} \odot$ \\ L. L. Guan, ${ }^{1}$ (1) and M. A. Steele ${ }^{1,5 *}$ (1) \\ ${ }^{1}$ Department of Agricultural, Food and Nutritional Science, University of Alberta, Edmonton T6G 2P5, Canada \\ ${ }^{2}$ Lallemand SAS, F-31702 Blagnac, France \\ ${ }^{3}$ Lethbridge Research Center, Agriculture and Agri-Food Canada, Lethbridge, AB T1J 4B1, Canada \\ ${ }^{4}$ Lallemand Specialties Inc, Milwaukee, WI 53218 \\ ${ }^{5}$ Department of Animal Biosciences, University of Guelph, Guelph, ON N1G 2W1, Canada
}

\section{ABSTRACT}

The early development of immunity and microbiota in the gut of newborn calves can have life-long consequences. Gut microbiota and the intestinal barrier interplay after birth, establishing a homeostatic state whereby mucosal cells cohabit with microorganisms to develop a healthy gut. We hypothesized that postnatal codevelopment of gut immunity and microbiota could be influenced by early-life supplementation with live yeast. Starting from birth, calves either received a daily supplementation of Saccharomyces cerevisiae boulardii CNCM I-1079 (SCB, $\left.10 \times 10^{9} \mathrm{cfu} / \mathrm{d}, \mathrm{n}=10\right)$ in the morning meal for $7 \mathrm{~d}$ or no supplementation $(\mathrm{n}=10)$. Each animal received 2 adequate colostrum replacer meals at 2 and $12 \mathrm{~h}$ of life (expected total $\mathrm{IgG}$ fed $=300 \mathrm{~g}$ ) before being fed milk replacer twice a day. Passive transfer of immunity (total protein, IgG, and $\operatorname{IgA}$ ) through colostrum was evaluated and endogenous production of $\operatorname{Ig} \mathrm{A}$ was investigated by measuring $\operatorname{IgA}$ producing plasma cells, IgA relative gene expression (PIGR and CD79A), and secretory IgA concentration in the gut. The concentration of targeted microbial groups was evaluated with quantitative PCR in the gut digesta collected at d 7 of life. Early SCB supplementation did not impair immunoglobulin absorption and all calves had successful passive transfer of immunity (serum IgG concentration $>15 \mathrm{mg} / \mathrm{mL}$ at $\mathrm{d} 1$ and $\mathrm{d} 7$ of age). Although the expression of $\operatorname{IgA}$ relative gene expression (PIGR and CD79A) was not different, SCB calves had higher secretory IgA concentrations in the ileum (1.98 $\pm 0.12 \mathrm{mg} / \mathrm{g}$ of dry matter; DM) and colon $(1.45 \pm 0.12$ $\mathrm{mg} / \mathrm{g}$ of $\mathrm{DM}$ ) digesta compared with control animals (1.18 and $0.59 \pm 0.12 \mathrm{mg} / \mathrm{g}$ of $\mathrm{DM}$, respectively). In

Received January 28, 2020.

Accepted April 22, 2020.

*Corresponding author: masteele@uoguelph.ca addition, the number of IgA-producing plasma cells were greater in both ileum $\left(2.55 \pm 0.40\right.$ cells $\left./ \mathrm{mm}^{2}\right)$ and colon $\left(3.03 \pm 0.40\right.$ cells $\left./ \mathrm{mm}^{2}\right)$ tissues for SCB calves compared with control (respectively $1.00 \pm 0.40$ and $0.60 \pm 0.42$ cells $/ \mathrm{mm}^{2}$ ). Endogenous IgA production in the gut of SCB calves was enhanced, which could make them less prone to pathogen intrusion. In addition, SCB calves had higher Lactobacillus and tended to have higher Faecalibacterium prausnitzii in the jejunum compared with control calves, which suggests that SCB supplementation during early-life gut colonization may have a positive effect in newborn calves. Direct SCB supplementation or the cross-talk between SCB and bacteria may be responsible for stimulating $\operatorname{IgA}$ production and may play a key role in shaping early colonization in the gut of newborn calves.

Key words: supplementation, immunoglobulin, yeast, immunity

\section{INTRODUCTION}

For decades, producers and researchers have known that calves are born with a naïve immune system, which means that early passive transfer of immunity plays a crucial role in defense against infectious diseases during the neonatal period (Famulener, 1912). An adequate uptake of maternal immunoglobulins, cytokines, bioactive compounds, and cells through colostrum and milk feedings in early life is therefore a key point in calf management to prevent disease. Even though all of the cellular components required for acquired immune response are already present in the fetus at 8 mo of gestation (Wilson et al., 1996), agammaglobulinemic newborn calves lack immune competence and the ability to respond to foreign antigens so as to minimize the fitness costs of infection (Owens and Wilson, 1999).

Antimicrobials are widely used on farms to treat and prevent disease in early life for cattle. Digestive and 
respiratory diseases are the most common infections affecting preweaned heifers, and overall 16.0 and $11.4 \%$ of heifers were treated for the aforementioned disease, respectively, in the United States in 2013 (NAHMS, 2014). This high percentage of therapeutic treatments applied during a short period of an animal's life underscores the poor immune status of newborns who need to be supported when they face the adversity of the nonsterile ex utero environment.

Given the high incidence of diarrhea and respiratory disease in neonatal calves, protection at the mucosal level is of great interest because it could decrease the risk of infection at this stage as well as reduce the use of antimicrobials, which may reduce antimicrobial resistance. The specific secretory $\operatorname{IgA}(\mathbf{S I g A})$ isotype, a noninflammatory antibody as a secretory form, is the most abundant immunoglobulin in mucosal secretions and represents only $7 \%$ of total immunoglobulin composition from bovine colostrum (Stelwagen et al., 2009). It has been reported in mice that sIgA favors the development of noninvasive commensal bacteria and provides protection against enteric pathogens through multiple mechanisms such as mucus-binding properties, which serve to trap bacteria in the mucus layer, stimulate biofilm formation, and limit access of bacteria to the epithelial surface (Johansen et al., 1999; Strugnell and Wijburg, 2010). Therefore, if endogenous sIgA production can be stimulated early in life, it will be a primary protective asset to defend against microbial pathogens and to promote the colonization of beneficial bacteria at mucosal surfaces. Nevertheless, in a study conducted with colostrum-deprived calves, even if endogenous production of IgM was detected from $4 \mathrm{~d}$ after birth, IgA concentration did not reach functional levels $(1 \mathrm{mg} / \mathrm{mL})$ in blood before $8 \mathrm{~d}$ of age (Chase et al., 2008) and appreciable blood concentration of $\operatorname{IgA}$ and $\operatorname{IgG}$ were only detected after $16 \mathrm{~d}$ of life (Husband and Lascelles, 1975).

Probiotics are live, nonpathogenic microorganisms that exert a beneficial influence on the health and physiology of the host. Recently, Saccharomyces cerevisiae boulardii CNCM I-1079 (SCB) has led to a better ADG in male dairy calves after weaning (Renaud et al., 2019) and reductions in the incidence of severe diarrhea in milk-fed dairy calves (Villot et al., 2019) when supplemented daily. This probiotic is largely used in humans for the treatment of acute-infectious enteritis and antibiotic-induced gastrointestinal disorders (Doron et al., 2008; McFarland, 2010; Choi et al., 2011). Indeed, numerous modes of action have been demonstrated in rodent models, such as improvements in intestinal health, stimulation of innate immunity, and increased protection against pathogens (McFarland et al., 2018). The stimulation of sIgA release from the gut is one of the immunoprotective effects of SCB that has been demonstrated in adult rats (Buts et al., 1990), gnotobiotic mice (Rodrigues et al., 2000), and broiler chickens (Rajput et al., 2013). However, information regarding the ability of newborn calves to produce IgA when supplemented with SCB is lacking. Thus, we hypothesized that postnatal microbiota colonization and endogenous IgA production in the gut of newborn calves could be influenced by early-life supplementation with live yeast. The objective of this study was to assess the ability of 1-wk-old calves to produce $\operatorname{sg} \mathrm{A}$ and to investigate the effect of early SCB supplementation on IgA production and microbial colonization in the gut.

\section{MATERIALS AND METHODS}

\section{Animals and Diets}

This experiment was conducted at the Dairy Research and Technology Centre (DRTC) of the University of Alberta under the approval of the University of Alberta Animal Care and Use Committee for Livestock (AUP00002645). Holstein heifers and cows were moved to maternity pens 3 to $10 \mathrm{~d}$ before expected parturition. A birth-monitoring sensor (iVET, Papenburg, Germany) was inserted intravaginally to detect the start of the calving process of each cow. Singlet calves that were naturally delivered were removed from the maternity pen immediately after birth to avoid any contact with the dam. A total of 20 Holstein bull calves born from May to August 2018 with a birth BW between 35 and $55 \mathrm{~kg}$ were enrolled in this study. The sample size of 10 animals per group was based on identifying a difference in the gut of total bacteria concentration between the control (CON) and SCB groups of $0.8 \log _{10} \mathrm{cfu} / \mathrm{g}$ of sample, confidence level of $95 \%$, and power of $95 \%$. The POWER procedure of SAS (version 9.0, SAS Institute Inc., Cary, NC) was used to perform the statistical analysis. Birth BW was recorded before moving calves to individual and disinfected indoor pens $(150 \times 125$ $\mathrm{cm}$ ) bedded with a consistent amount of fresh straw to facilitate nesting. Newborns were randomly assigned according to their date of birth and initial BW to a unique pen referring to 1 of the 2 dietary treatments for 1 wk. All calves were then dried with clean towels for $10 \mathrm{~min}$ and navel-dipped using 7\% iodine before the start of any procedures. Animals included in this study presented healthy at birth based on general appearance, rectal temperature, umbilical appearance, and nasal discharge; none were vaccinated or treated with therapeutic fluids during the trial.

Calves received 2 meals of standardized colostrum replacer (HeadStart, Saskatoon Colostrum Co. Ltd., Saskatoon, SK, Canada) at $2 \mathrm{~h}$ (675 g of colostrum 
powder diluted to match a volume of $7 \%$ of birth BW, expected $\operatorname{IgG}$ fed $=180 \mathrm{~g}$ ) and $12 \mathrm{~h}(450 \mathrm{~g}$ of colostrum powder diluted to match a volume of $3 \%$ of birth BW, expected $\operatorname{IgG}$ fed $=120 \mathrm{~g}$ ). The colostrum powder (550 $\mathrm{g} / \mathrm{kg}$ of $\mathrm{CP}, 100 \mathrm{~g} / \mathrm{kg}$ of crude fat, total viable aerobic count $<5 \times 10^{5} \mathrm{cfu} / \mathrm{g}$ ) was suspended in warm water $\left(42^{\circ} \mathrm{C}\right)$ to make the final volume required for each calf and fed initially by bottle. The remainder of the meal volume was tube-fed if the calves did not consume all of the meal within $30 \mathrm{~min}$. Calves were subsequently bottle-fed 2 meals of milk replacer (MR: $150 \mathrm{~g}$ of powder mixed with water at $42^{\circ} \mathrm{C}$ to make $1 \mathrm{~L}$ of solution) daily at 0700 and $1900 \mathrm{~h}$, respectively. The MR used in this study contained $260 \mathrm{~g} / \mathrm{kg}$ of CP, $160 \mathrm{~g} / \mathrm{kg}$ of crude fat, and $4.58 \mathrm{Mcal} / \mathrm{kg}$ of ME on a DM basis (Grober Animal Nutrition, Cambridge, Ontario, Canada). The initial volume of individual meals offered to each calf was $7.5 \%$ of their birth BW during the 2 first days of the experiment and increased to $8.5 \%$ of $\mathrm{BW}$ from $\mathrm{d}$ 3 to $d$ 7. Individual refusals of MR were recorded at each feeding and calves were given ad libitum access to water. The calves assigned to the treatment group (SCB) were supplemented throughout the experiment with the same daily quantity of $5 \mathrm{~g}$ of live SCB (ProTernative Milk; Levucell SB20 containing the Pasteur Institute of SCB strain; Lallemand Animal Nutrition, Montreal, Quebec, Canada). The supplementation was added in the first colostrum feeding, and subsequently in each MR morning feeding, which was expected to supply $10 \times 10^{9} \mathrm{cfu}$ of SCB per day. To ensure total consumption of the supplementation, a premorning meal was prepared by mixing $5 \mathrm{~g}$ of SCB with $260 \mathrm{~mL}$ of either colostrum or MR solution, and was fed first to the SCB calves before they received the remaining part of their meal. The other 10 calves $(\mathrm{CON})$ did not receive supplementation in any of their meals during the entire experiment.

\section{Blood Collection}

Jugular blood samples were taken within $1 \mathrm{~h}$ of birth before the initial colostrum feeding and immediately before the second colostrum meal at $12 \mathrm{~h}$ using serum evacuated tubes (Fisher Scientific, Nepean, ON, Canada). Blood samples were then collected every day before the morning meal using a 2-in, 16-gauge catheter (Thermo Fisher Scientific, San Diego, CA) inserted into the jugular vein at $\mathrm{d} 1$ of life for the duration of the experiment. Immediately after sample collection, aprotinin (Sigma-Aldrich, St. Louis, MO) was added to the blood sample collected in a heparinized tube (in the ratio of 500 kallikrein inhibitor units $/ \mathrm{mL}$ of blood) before centrifugation at $3,000 \times g$ at $4^{\circ} \mathrm{C}$ for $20 \mathrm{~min}$ for plasma preparation. A second serum tube (Fisher
Scientific, Nepean, ON, Canada) was incubated at room temperature for $3 \mathrm{~h}$ to coagulate, and serum was collected after centrifugation at $3,000 \times g$ at $4^{\circ} \mathrm{C}$ for 20 min. Serum and plasma were aliquoted into three 1.5$\mathrm{mL}$ microcentrifuge tubes and stored at $-20^{\circ} \mathrm{C}$ until further analysis for immunoglobulin concentrations.

\section{Intestinal Tissue and Gut Digesta Sampling}

Intestinal samples were collected from each calf at $1 \mathrm{wk}$ of life and $3 \mathrm{~h}$ after the morning meal. Fecal samples (20 g) were collected via rectal palpation before euthanasia and immediately snap-frozen in liquid nitrogen. Calves were euthanized with a pentobarbital sodium injection (Euthanyl, Vetoquinol, Lavaltrie, QC, Canada) at $0.125 \mathrm{~mL} / \mathrm{kg}$ of BW administered through a jugular catheter. Once the calf reached a surgical plane of anesthesia, exsanguination was performed. The esophagus and rectum were first ligated to prevent loss of content and the entire gut contents were then removed with caution to avoid transfer of contents between the different segments. Following this, 15-cmlong intestinal segments of predefined gut regions were collected. The proximal jejunum was defined as $100 \mathrm{~cm}$ distal to the pylorus sphincter, the ileum segment was defined as $30 \mathrm{~cm}$ proximal to the ileocecal junction, and the colon segment was defined as $30 \mathrm{~cm}$ distal to the ileocecal junction (Malmuthuge et al., 2015). Intestinal contents were removed from the sample using tweezers and placed in a 50-mL Falcon tube. The tissue was then washed in sterile PBS $(\mathrm{pH}$ 7.4) until clean $(\sim 3-4$ washes) and placed in a sterile bag. Both gut content and tissue samples were immediately snap-frozen in liquid nitrogen and then stored at $-80^{\circ} \mathrm{C}$ until further processing.

\section{Quantification of Proteins in Serum, Gut Digesta, and Colostrum}

Daily serum samples were analyzed by the Saskatoon Colostrum Company quality assurance laboratory (SCCL Ltd. Saskatoon, SK, Canada) for determination of total protein and IgG concentrations by radial immunodiffusion analysis according to the protocol as described by Shivley et al. (2018). The same method was used to verify the $\operatorname{IgG}$ concentration in the single pooled colostrum batch fed to the calves at birth. The concentration of IgA was analyzed using a sandwich ELISA technique with a commercial kit (Bethyl Laboratories Inc., TX) in serum samples collected $12 \mathrm{~h}$ after birth and at $\mathrm{d} 7$, in the gut digesta (jejunum, ileum, and colon) at d 7, as well as in the standardized colostrum fed to the calves. A total of $500 \mathrm{mg}$ of colostrum was suspended directly in $50 \mathrm{~mL}$ of the 
extraction buffer. Blood serum was diluted with PBS ranging from 1 to 1:2,500 to fall within the concentration range of the standards. Approximately $200 \mathrm{mg}$ of gut digesta samples were weighed in a 2-mL sterile tube and subsequently vacuum dried in a Speed Vac concentrator (Jouan RC1022, Savant Instruments, Inc., Farmingdale, NY) for $3 \mathrm{~h}$ at 1,200 rpm with no heat. The net dry weights ranging from 18 to $70 \mathrm{mg}$ were recorded for each sample before adding $25 \mu \mathrm{L}$ of an extraction buffer (PBS $+0.05 \%$ Tween $+0.02 \%$ sodium azide + protease inhibitor cocktail) for each milligram of dry content. Samples were thoroughly homogenized through a combination of manual shaking and mechanical homogenization on a vortex mixer until full resuspension. Before centrifugation at 2,800 $\times g$ for $10 \mathrm{~min}$, supernatants were collected in a fresh tube for ELISA analysis according to the manufacturer's instructions (Bethyl Laboratories Inc.). A specific purified sheep anti-bovine IgA antibody (ELISA coating Buffern, E107, Bethyl Laboratories Inc.) was used to coat the plate. Results were expressed as micrograms of sIgA per gram of DM. All samples were tested in duplicate. Samples with an intraassay coefficient of variation $(\mathbf{C V} ; \% \mathrm{CV}$ $450 \mathrm{~nm})$ greater than $10 \%$ were repeated, as well as plates with an interassay CV superior to $10 \%$.

\section{Immunohistochemistry of IgA-Producing Plasma Cells}

All of the tissue sections were examined using an indirect immunohistochemistry method. The samples were fixed in buffered formalin $(10 \%$, wt/vol) for $12 \mathrm{~h}$, washed with PBS, processed with routine histological protocols, and embedded in paraffin. In brief, sections were deparaffinized and rehydrated, and then antigen retrieval was performed using heat retrieval in pressure with Target Retrieval Solution at pH 6.0 (Dako/ Agilent, cat. \# S1699, Carpinteria, CA). Between 3 and 4 cut sections at $4-\mu \mathrm{m}$ thickness were performed with a rotary microtome, mounted on slides. Endogenous peroxidase activity was inhibited with $3 \%$ hydrogen peroxide, and nonspecific binding was blocked with $10 \%$ normal goat serum. First, all sections were incubated with primary antibodies, rabbit anti-bovine IgA (Novus; cat. \# NB770 dilution 1:4,800, Centennial, CO), for 30 min. Then, after being washed in Tris buffer saline with Tween, the samples were incubated for $30 \mathrm{~min}$ with secondary antibodies, EnVision+ goat anti-rabbit IgG conjugated with horseradish peroxidase (Dako/Agilent; cat. \#: K4003), with $6 \%$ normal bovine serum added per volume. The detection of immunoreactivity of antigens was with 3-amino-9-ethylcarbazole (Dako/Agilent; cat. \# K3464) for 15 min. Finally, the slides were washed in tap water, counter-stained with Mayer's hematoxylin, and coverslipped using Glycergel (Dako/Agilent; cat. \# C0563). Positive control of a 5-yr-old lactating dairy cow's colon tissues was used. Negative control sections of each gut section for $1 \mathrm{CON}$ and $1 \mathrm{SCB}$ calves were subjected to the same immunohistochemical method, replacing primary antibodies with diluted normal rabbit serum. Each cut section was imaged with a magnification of $0.67 \times$ using a light microscope with an eyepiece magnification of $10 \times$ (Olympus SZ61, Japan) and optronics digital camera (PictureFrame version 2.3, Optronics, Goleta, CA). Only cuts with nondamaged and well oriented villi and crypts under the microscope were used for the IgA-producing $(\mathbf{I g} \mathbf{A}+)$ plasma cell enumerations. The total area $\left(\mathrm{mm}^{2}\right)$, including mucosa and submucosa, of each cut section was evaluated using the color segmentation tool in the tones and intensities of ImageJ software (Schneider et al., 2012). The total number of IgA + plasma cells within the measured area were counted using a light microscope (eyepiece magnification 10×, Zeiss Axio Scope A1, Oberkochen, Germany) with a $10 \times$ magnification objective. The immunohistochemical staining of $\operatorname{IgA}+$ plasma cell showed a circle and intense brown cytoplasmic staining for $\mathrm{IgA}+$ plasma cells mainly in the lamina propria (LP) of the tissue. The number of IgA+ plasma cells were reported per square millimeter of tissues enumerated. For each sample, 3 different cuts were quantified and each measurement was repeated by 3 individuals.

\section{The RNA Extraction and Expression of IgA Related Genes}

We extracted RNA from the proximal jejunum, ileum, and colon tissue samples. Tissues were ground $(\sim 0.1 \mathrm{~g})$ in liquid nitrogen before RNA extraction. Samples were then homogenized with TRIzol (Invitrogen, Grand Island, NY) and CK-14 Precellys lysine kit (Bertin Technologies, Montigny, France) using a Precellys homogenizer. Then, the lysate was treated with chloroform, isopropanol, and high salt solution (1.2M $\mathrm{NaAc}, 0.8 \mathrm{M} \mathrm{NaCl}$ ) sequentially. The RNA was precipitated using cold ethanol and dissolved in nuclease-free water $(200 \mu \mathrm{L})$. The RNA concentration was measured using NanoDrop 1,000 spectrophotometer (NanoDrop Technologies, Wilmington) and Qubit 3.0 Fluorometer (Invitrogen, Carlsbad, CA) and the RNA integrity number was measured using Agilent 2200 Tape station (Agilent Technologies, Santa Clara, CA). The real-time (RT)-qPCR analysis was performed to evaluate gene expression of PIGR encoding for the Polymeric Immunoglobulin Receptor and of $C D^{79} \mathrm{~A}$ encoding for B-cell antigen receptor complex-associated protein $\alpha$ chain using primers reported in Table 1 . We chose $A C T B$ and $G A P D H$ as the housekeeping genes out of 4 genes 
tested with all of the mucosal tissue samples $(A C T B$, $G A P D H$, ribosomal protein large $\mathrm{P} 0$, and $18 \mathrm{~S}$ rRNA) using geNorm analysis (Vandesompele et al., 2002). The cDNA was synthesized by using iScript reverse transcription Supermix from Bio-Rad (Bio-Rad Laboratories, Hercules, CA) and used for RT-qPCR analysis. The RT-qPCR was performed using $1 \mu \mathrm{L}$ of $50 \mathrm{ng} /$ $\mu \mathrm{L}$ of amplified RNA as the template and the following program: $95^{\circ} \mathrm{C}$ for $15 \mathrm{~s}$, followed by 40 cycles of $95^{\circ} \mathrm{C}$ for $3 \mathrm{~s}$ and $60^{\circ} \mathrm{C}$ for $30 \mathrm{~s}$ in ViiA 7 Real-Time PCR (Applied Biosystems, Foster City, CA). Finally, a melt curve was generated at $95^{\circ} \mathrm{C}$ for $15 \mathrm{~s}, 60^{\circ} \mathrm{C}$ for $1 \mathrm{~min}$, and $95^{\circ} \mathrm{C}$ for $15 \mathrm{~s}$. Gene expression $(\Delta \mathrm{Cq}$ value) was calculated based on quantification cycle $(\mathbf{C q})$ of average housekeeping genes (mean of $A C T B+G A P D H$ ) and target gene (PIGR and CD $79 A ; \Delta \mathrm{Cq}=\mathrm{Cq}$ target gene - mean of Cq housekeeping genes).

\section{Quantification of Microbial Groups in Intestinal Digesta}

The total DNA from intestinal digesta was extracted using the repeated bead beating plus column method (Yu and Morrison, 2004). Briefly, the digesta sample $(\sim 0.3 \mathrm{~g} \pm 0.1 \mathrm{~g})$ was washed twice with Tris-EDTA buffer. After the addition of cell-lysis buffer containing $4 \%$ SDS, samples were subjected to physical disruption at 5,000 rpm for 3 min using Biospec Mini Beads Beater 8 (BioSpec, Bartlesville, OK), followed by incubation at $70^{\circ} \mathrm{C}$ for $15 \mathrm{~min}$ and centrifugation for $5 \mathrm{~min}$ at $16,000 \times g$ at $10^{\circ} \mathrm{C}$. The bead beating, incubation, and centrifugation were repeated once and impurities were removed from the supernatant using $10 \mathrm{M}$ ammonium acetate, followed by DNA precipitation using isopropanol. After precipitation, DNA was further purified using QIAmp fast DNA stool mini kit (Qiagen Inc., Germantown, MD). The quantity and purity of DNA were evaluated using the NanoDrop 1,000 spectrophotometer, and DNA was stored at $-20^{\circ} \mathrm{C}$ until further use.

The abundances of total bacteria, Bifidobacterium, Lactobacillus, Faecalibacterium prausnitzii, and total Escherichia coli were estimated by measuring their respective 16S rRNA gene copy numbers using qPCR. The qPCR was performed using SYBR green chemistry (Fast SYBR Green Master Mix, Applied Biosystems) with specific primers (Table 1) in the highthroughput ViiA $^{\text {TM }} 7$ Real-Time PCR System (Thermo Fisher Scientific, Waltham, MA). Standard curves were generated for each bacterial group using purified plasmid carrying 16S rRNA genes of Butyrivibrio hungatei, Bifidobacterium adolescentis, Lactobacillus acidophilus ATCC4356, F. prausnitzii A2-165, and E. coli K12, respectively. The copy number of $16 \mathrm{~S}$ rRNA gene per gram of fresh

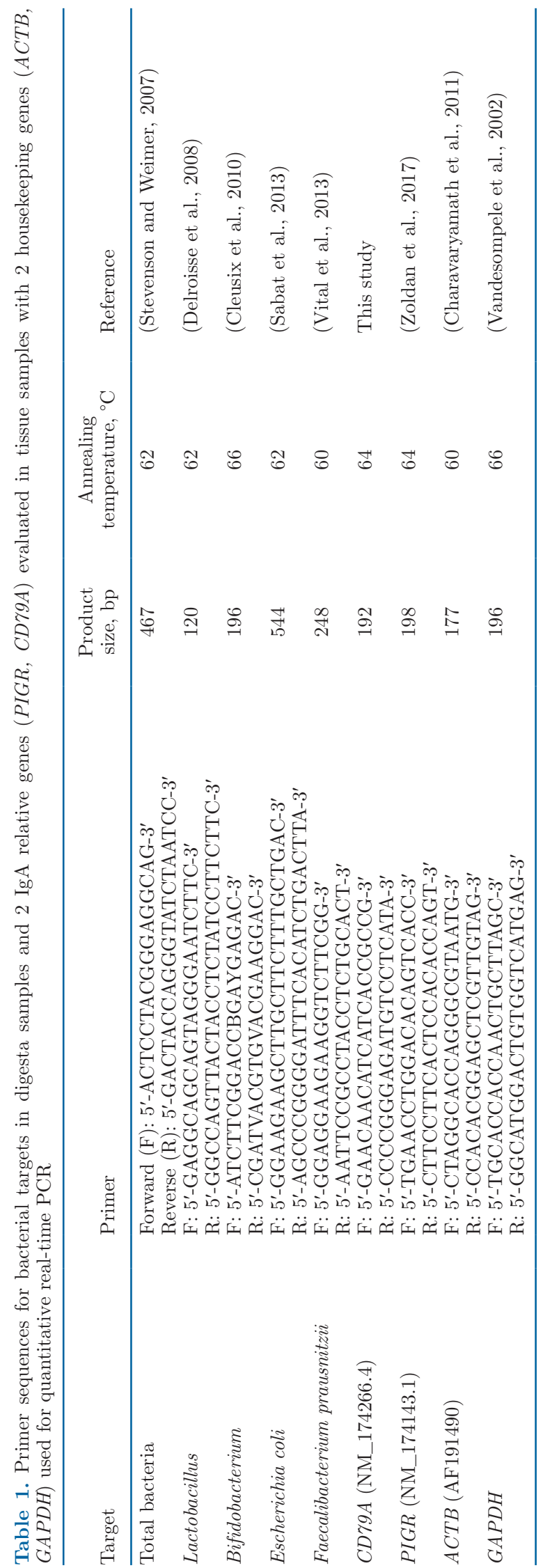


matter was calculated using the equation described by Li et al. (2009).

A direct enumeration of total viable yeast was performed in the feces of the first 10 calves (half $\mathrm{CON}$ and half SCB) of the experiment to validate the SCB supplementation. Approximately $5 \mathrm{~g}$ of fresh feces collected on d 7 was serially diluted in peptone water $(0.1 \%)$ from $10^{-2}$ to $10^{-6}$ and incubated inverted at $30^{\circ} \mathrm{C}$ for $3 \mathrm{~d}$ with the presence of oxygen on Sabouraud agar plates ( $5 \mathrm{~g}$ of yeast extract, $20 \mathrm{~g}$ of glucose, and $15 \mathrm{~g}$ of agar qsp (solubility product quotient) for $1 \mathrm{~L}$ of distilled water, $\mathrm{pH}=7.2$ ) supplemented with $0.2 \mathrm{~g} / \mathrm{L}$ of chloramphenicol. A direct enumeration of total viable yeast was performed on the appropriate plates showing between 30 and 150 colonies.

\section{Statistical Analysis}

To determine the effect of SCB supplementation, all data were analyzed using the MIXED procedure of SAS software. For serum total protein, IgG, and IgA concentrations, repeated measures of time were used with the model, including the fixed effects of dietary treatment, time, and treatment by time interaction. The fixed effects of parity and the mode of colostrum feeding (tubing or bottle-fed) were tested but were not included in the model because they were not significant. For the bacterial targets (Bifidobacterium, Lactobacillus, E. coli, F. prausnitzii, and total bacteria), the sIgA concentration, and the number of $\operatorname{Ig} \mathrm{A}+$ plasma cells, data were analyzed with gut location as the repeated measure and calf as the experimental unit using compound symmetry covariance structure, which was selected as the best fit by the Bayesian information criterion. When a treatment effect occurred, individual comparisons using the PDIFF adjusted $=$ Bonferroni statement of SAS was performed by location or time. All values reported are least squares means with sig- nificance declared at $P \leq 0.05$ and tendencies at 0.05 $<P<0.10$.

\section{RESULTS}

No colonies of viable yeast were detected in the feces collected at $\mathrm{d} 7$ for the first $5 \mathrm{CON}$ calves (dilution $10^{-3}$, live yeast concentration lower than $\left.1 \times 10^{4} \mathrm{cfu} / \mathrm{g}\right)$. The validity of SCB supplementation was confirmed in the first $5 \mathrm{SCB}$ calves with an average count of $5.3 \pm$ $0.08 \log _{10} \mathrm{cfu} / \mathrm{g}$ of viable yeast quantified.

\section{Immune Status of the Newborn Calves}

Each calf received a total of $310.5 \mathrm{~g}$ of $\operatorname{IgG}(276 \mathrm{mg}$ of $\mathrm{IgG} / \mathrm{g}$ of dry powder, radial immunodiffusion measurements) within $12 \mathrm{~h}$ of life (186.3 g at $2 \mathrm{~h}$ of life and $124.2 \mathrm{~g}$ at $12 \mathrm{~h}$ of life). Seven calves voluntarily consumed their 2 colostrum meals within $30 \mathrm{~min}$ and 13 calves ( 5 in CON and 8 in SCB group) were tubefed a portion of the colostrum feeding to ensure total consumption. No differences between the total protein, IgG, and IgA passive transfer of CON and SCB calves were detected and the colostrum tubing did not affect the absorption level (every calf had over $15 \mathrm{mg}$ of $\mathrm{IgG} /$ $\mathrm{mL}$ of serum at both $12 \mathrm{~h}$ after birth and 1 wk of age; $P=0.663$, Table 2, Figure 1). The concentration of IgA in the colostrum was detected at $5.3 \mathrm{mg} / \mathrm{g}$ of dry powder (ELISA technique) and each calf received $6.0 \mathrm{~g}$ of $\operatorname{IgA}$ within $12 \mathrm{~h}$ of birth $(3.6 \mathrm{~g}$ at $2 \mathrm{~h}$ of life and 2.4 $\mathrm{g}$ at $12 \mathrm{~h}$ of life). The serum IgA concentration was not different at $12 \mathrm{~h}$ after birth for $\mathrm{CON}$ and SCB calves $(0.762$ and $0.731 \pm 0.070 \mathrm{mg} / \mathrm{mL}$ respectively; $P=$ 0.663 , Table 2). At d 7, similar concentrations of serum IgA were measured for CON and SCB calves $(0.343$ and $0.226 \pm 0.097 \mathrm{mg} / \mathrm{mL}$ respectively; $P=0.248$, Table $2)$, and both were decreased $(P<0.001)$ compared with $12 \mathrm{~h}$ after birth.

Table 2. Serum concentration of total protein, $\operatorname{IgA}$, and $\operatorname{IgG} 12 \mathrm{~h}$ after birth (d 0 ) and at $\mathrm{d} 7$ of life in response to the supplementation of Saccharomyces cerevisiae boulardii CNCM I-1079 in neonatal calves

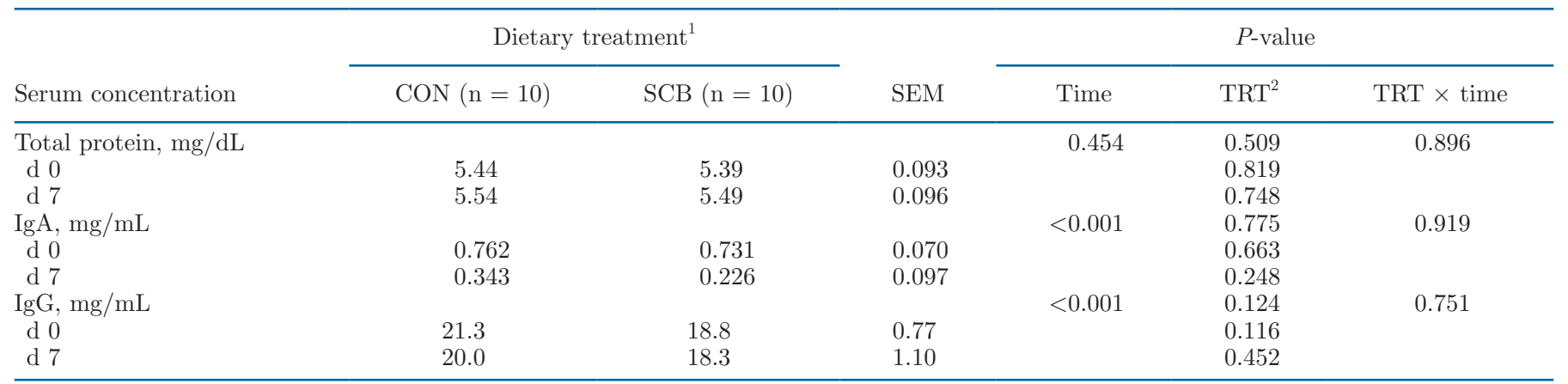

${ }^{1} \mathrm{CON}=$ nonsupplemented calves; SCB $=$ calves supplemented with S. cerevisiae boulardii $\mathrm{CNCM}$ I-1079 at $10 \times 10^{9}$ cfu/d. Values are LSM. ${ }^{2} \mathrm{TRT}=$ dietary treatment. 


\section{Secretory IgA and IgA+ Plasma Cells Quantification in the Gut of 1-wk-old Calves}

The $\operatorname{sIg}$ A concentration in the jejunum $(0.21 \pm 0.06$ $\mathrm{mg} / \mathrm{g}$ of $\mathrm{DM})$ was not affected $(P=0.938)$ by the dietary treatment and was lower compared with the ileum $(1.58 \pm 0.18 \mathrm{mg} / \mathrm{g}$ of DM, $P<0.001$, Figure 2$)$. The concentration of sIgA in the ileum $(+0.8 \mathrm{mg} / \mathrm{g}$ of $\mathrm{DM}$ digesta) and colon $(+0.86 \mathrm{mg} / \mathrm{g}$ of DM digesta) in 1-wk-old SCB calves were higher than in CON calves $(P<0.01$, Figure 2$)$. Intra- and interassay $\mathrm{CV}$ were 8.9 and $7.5 \%$, respectively.

Few IgA+ plasma cells were detected in the jejunum section (data not shown) and IgA+ plasma cells were mainly distributed in the dome region of Peyer's patches $(\mathbf{P P})$, the interfollicular area, villi of the ileum sections, and the crypts in the colon section (Figure 3 ). The number of IgA+ plasma cells per square millimeter was greater in the gut of SCB calves, with an average of $3.03 \mathrm{IgA}+$ plasma cells $/ \mathrm{mm}^{2}$ in the colon of SCB calves compared with $0.60 \mathrm{IgA}+$ plasma cells in the CON calves $(\mathrm{SEM}=0.52, P<0.001$, Table 3 ) and $2.55 \mathrm{IgA}+$ plasma cells $/ \mathrm{mm}^{2}$ in the ileum of SCB calves compared with $1.0 \mathrm{IgA}+$ plasma cells $/ \mathrm{mm}^{2}$ in the CON calves $(\mathrm{SEM}=0.63, P=0.012$, Table 3 ).

No difference in terms of gene expression for IgArelated genes was observed between the 2 dietary treatments $(P>0.05$, Table 3$)$, but significant gut-section dependent gene expression was observed for both $C D 79 A$ and PIGR along the intestines of calves $(P<$

A

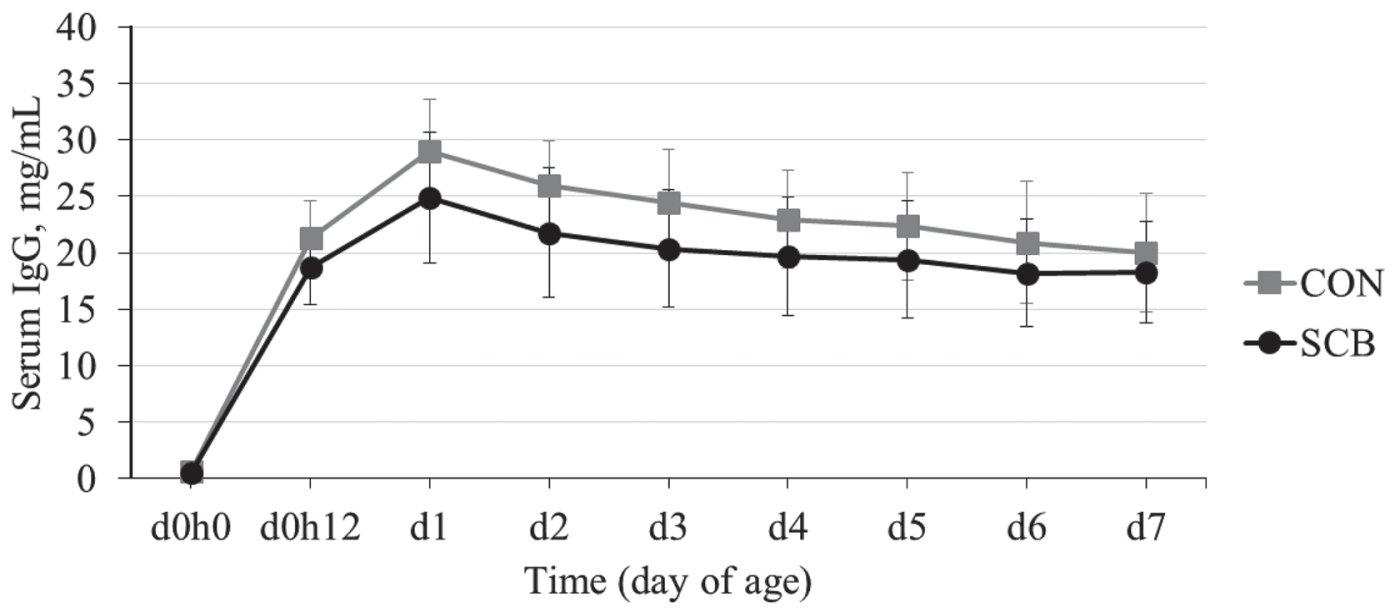

B

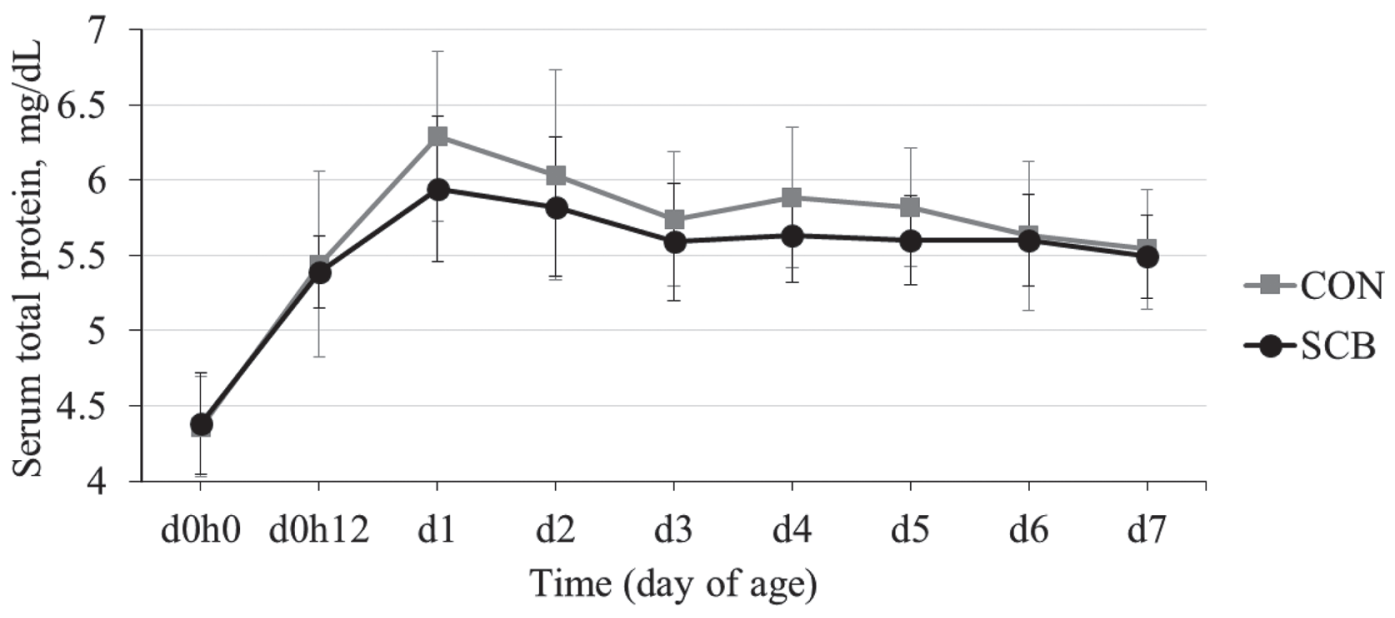

Figure 1. Daily serum concentration of $\operatorname{IgG}(\mathrm{A})$ and total protein $(\mathrm{B})$ measured from birth to 1-wk-old calves $(\mathrm{n}=20)$ in response to the supplementation of Saccharomyces cerevisiae boulardii CNCM I-1079 at $10 \times 10^{9} \mathrm{cfu} / \mathrm{d}$. Values are means $\pm \mathrm{SD}$. CON $=$ nonsupplemented calves; SCB = calves supplemented with S. cerevisiae boulardii CNCM I-1079. 
0.001, Table 3). Higher PIGR expression was detected in the jejunum and colon, whereas the $C D^{r} 79 A$ was highly expressed in the ileum $(P<0.001$, Table 3$)$.

\section{Changes in the Intestinal Bacteria Populations in Response to SCB Supplementation}

The total number of bacteria was lower in the ileum digesta of SCB calves at 1-wk-old (8.59 and $9.02 \pm 0.21$ $\log _{10} 16 \mathrm{~S}$ copy/g of sample for SCB and CON calves, $P=0.042)$, whereas no difference was detected in the jejunum and colon sections $(P>0.1)$. Concerning the bacterial groups, Lactobacillus spp. were higher $(P=$ 0.039) in the jejunum of SCB calves, and SCB calves had a tendency to have higher $F$. prausnitzii concentrations in the colon $(P=0.099)$ and jejunum $(P=0.090$, Table 4) compared with CON calves.

\section{DISCUSSION}

To our knowledge, this study is the first to report on the ability of healthy 1-wk-old calves to produce and release $\operatorname{sgA}$ at the mucosal surface of the gut. Early supplementation of $S$. cerevisiae boulardii CNCM I-1079 live yeast promoted IgA production, which could have shaped microbiota colonization toward a beneficial microbial ecosystem for gut health of the animals from birth.

Successful transfer of passive immunity was recorded for each animal after the colostrum feedings with an adequate amount of serum IgG $(>15 \mathrm{mg} / \mathrm{mL})$ throughout the first week of life (Furman-Fratczak et al., 2011). Previous work by James and Polan (1978) suggested that the early introduction of intestinal microorganisms through orally administered adult duodenal fluid with the colostrum meal can interfere absorption of colostral proteins in newborn calves. However, in the present study, we demonstrated that early SCB supplementation directly in the colostrum did not affect total protein absorption, and more specifically, IgG and IgA. Other studies in young calves demonstrated that using probiotics (multi-strain containing 7 bacteria strains and 2 yeast strains with $2 \times 10^{9} \mathrm{cfu} / \mathrm{g}$ ) and prebiotics (polysaccharides of $S$. cerevisiae cell wall) fed from d 4 of age had no effect on serum IgG concentrations after $26 \mathrm{~d}$ of supplementation (Roodposhti and Dabiri, 2012). This previous work demonstrates that supplementation of pre- and probiotics does not affect pre-established serum IgG concentrations, however our results further demonstrate that direct supplementation of live yeast within colostrum does not interfere with the absorption of IgG from colostrum into calf circulation.

The serum IgA concentrations observed at $12 \mathrm{~h}$ after birth were likely due to IgA absorbed directly from colostrum. Whereas a long half-life of $21 \mathrm{~d}$ for IgG in serum is reported, the half-life of IgA has been estimated at $2.8 \mathrm{~d}$ (Logan et al., 1973). Although this study could not determine any re-secretion of IgA (originating from colostrum) back into the intestine, the short half-life of IgA suggests that the significant reduction of serum

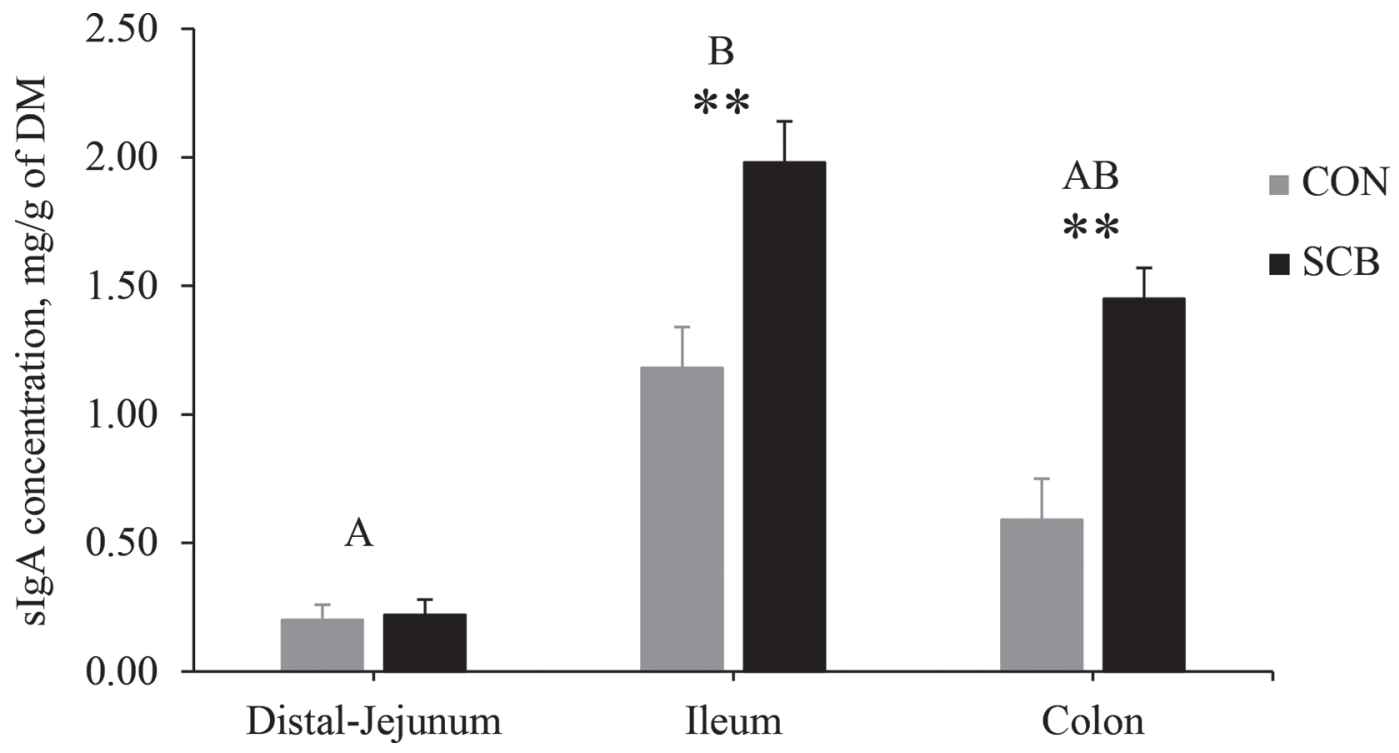

Figure 2. Secretory IgA (sIgA) concentration in the different segments of the gut of 1 -wk-old calves $(\mathrm{n}=20)$ in response to the supplementation of Saccharomyces cerevisiae boulardii CNCM I-1079 at $10 \times 10^{9} \mathrm{cfu} / \mathrm{d}$. Values are LSM \pm SEM. Different letters A and B indicate a significant difference between location in the gut, and $* *$ indicates a significant difference between $\mathrm{CON}$ and $\mathrm{SCB}$ groups $(P<0.05)$. CON $=$ nonsupplemented calves; SCB = calves supplemented with $S$. cerevisiae boulardii CNCM I-1079. 
IgA from $\mathrm{d} 1$ to $\mathrm{d} 7$ is likely due to the absence of exogenous IgA supply to the animal. A similar decrease of IgA concentration has been measured in the feces of calves fed maternal colostrum from d 2 to $\mathrm{d} 8$ of age (Quezada-Mendoza et al., 2011). A greater IgA concentration was then reported from d 8, when calves started to develop diarrhea, suggesting a cellular response to the onset of the clinically observed disease.

In this specific study, we demonstrated that SCB supplementation from birth directly in the colostrum did not impair passive immunity transfer, which is
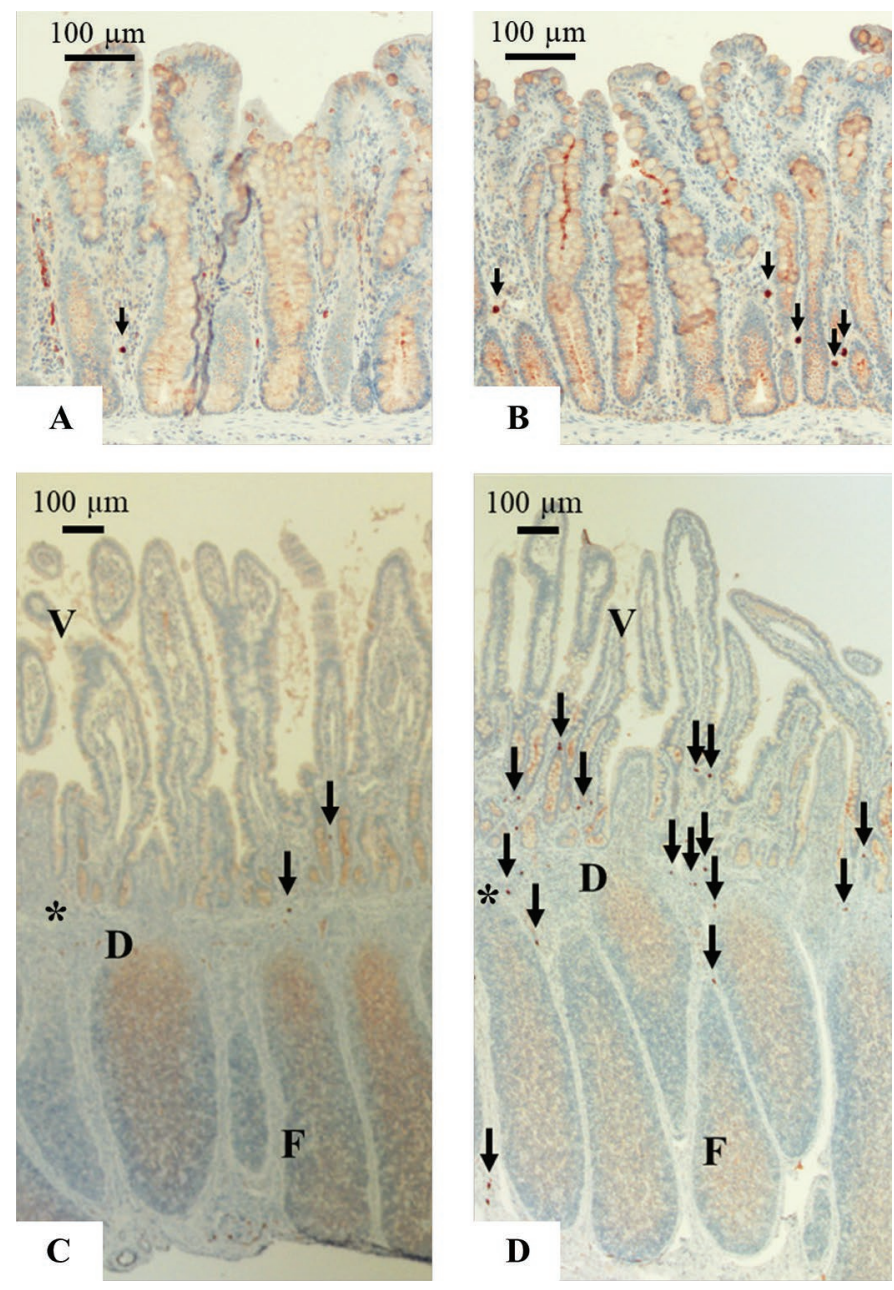

Figure 3. Immunohistochemical staining of IgA-producing plasma cells in colon mucosa of a 1-wk-old control calf (A) and a 1-wk-old calf supplemented daily with Saccharomyces cerevisiae boulardii CNCM I-1079 at $10 \times 10^{9} \mathrm{cfu} / \mathrm{d}(\mathrm{B})$, and ileal mucosa and submucosa of a 1-wk-old control calf (C) and a 1-wk-old calf supplemented daily with $S$. cerevisiae boulardii CNCM I-1079 at $10 \times 10^{9} \mathrm{cfu} / \mathrm{d}$ (D). IgAproducing plasma cells are stained in brown, well-delimited circles (arrowhead) and only localized in the lamina propria of the mucosal region in the colon. IgA-producing plasma cells were distributed in the lamina propria mainly in the dome region (d) of Peyer's Patches, the interfollicular area $(*)$, and the villi, but very few were within the follicles (f). a critical finding for ensuring the health of newborn calves. Residual amounts of IgA detected in the serum of 1-wk-old calves indicated no carry over effect from the colostrum IgA supply provided at birth.

The sIgA contributes to immune homeostasis by limiting access of microbial antigens, maintaining the integrity of the epithelial barrier, and shaping the composition of the commensal microbiota (Pabst et al., 2016). Although the benefits of sIgA production in mucosal secretions on immunity have been largely demonstrated and summarized in rodent models (Mantis et al., 2011), little information is available in ruminants even less so for newborns. The larger number of $\operatorname{Ig} \mathrm{A}+$ plasma cells, along with the enhanced concentration of sIgA, found in the gut digesta of 1-wk-old SCB calves suggests an early endogenous production and release of $\operatorname{sig} \mathrm{A}$ at the mucosal surface. The IgA + plasma cells were mainly distributed in the dome region of $\mathrm{PP}$, the interfollicular area, the villi in ileum tissue, and the crypts in the colon section (Figure 3), as described by Liebler et al. (1996) in 4-mo-old calves. It is important to note that the number of IgA+ plasma cells counted was very low at 1 wk of age (1-3 IgA+ plasma cells/ $\mathrm{mm}^{2}$ ), which seems consistent with the data reported in 4-d-old healthy calves (2.6 IgA-containing cells $/ \mathrm{mm}^{2}$; Allen and Porter, 1975). In this same experiment, using a fluorescent $\operatorname{IgA}$ staining procedure, 15 and 22 IgA-containing cells $/ \mathrm{mm}^{2}$ were reported in ileum and jejunum tissues of 5-wk-old calves, respectively (Allen and Porter, 1975).

Even if only a substantial and nonbiologically relevant concentration of IgA was reported in the blood of 2-wk-old calves (Chase et al., 2008), little is known about the potential endogenous production and role of IgA in the gut of 1-wk-old calves. Intestinal IgA originates from $B$ cells that are already present at birth, reaching a concentration of $3.95 \times 10^{2} / \mu \mathrm{L}$ (9\% of total lymphocytes) at $\mathrm{d} 6$ of age in calves (Baccili et al., 2018). The molecule CD79 $\alpha$ is a part of B-cell receptor complex and plays a functional role in B-cell signaling and class switching (Reth, 1992; DeFranco, 1993). Intestinal B cells undergo class switching to IgA and affinity maturation within organized follicular structures associated with the gut-associated lymphoid tissue, such as PP and isolated lymphoid follicles (Pabst et al., 2016). As previously reported by other researchers (Yasuda et al., 2004; Snoeck et al., 2006; Fries et al., 2011), and confirmed by our microscopic examination (Figure 3), a continuous patch of PP in newborn calves was located in the ileum tissue. Moreover, the expression of B-cell markers was consistently higher in the ileum compared with colon and jejunum tissues. Affinity matured and IgA class-switched B cells emerge from intestinal follicles and reside in the intestinal LP. 
Table 3. Markers of IgA production in the gut of 1-wk-old calves in response to the supplementation of Saccharomyces cerevisiae boulardii CNCM I-1079

\begin{tabular}{|c|c|c|c|c|c|c|}
\hline Item measured in gut digesta & \multicolumn{2}{|c|}{ Dietary treatment ${ }^{1}$} & SEM & \multicolumn{3}{|c|}{$P$-value } \\
\hline $\mathrm{IgA}+$ plasma cells, ${ }^{3}$ no. $/ \mathrm{mm}^{2}$ & & & & 0.930 & $<0.001$ & 0.279 \\
\hline Ileum & 1.00 & 2.55 & 0.63 & & 0.012 & \\
\hline Colon & 0.60 & 3.03 & 0.52 & & $<0.001$ & \\
\hline \multicolumn{7}{|l|}{ Gene expression, $\Delta$ Cq value ${ }^{4}$} \\
\hline PIGR & & & & $<0.001$ & 0.655 & 0.848 \\
\hline Colon & 0.80 & 0.85 & 0.259 & & 0.960 & \\
\hline$C D 79 A$ & & & & $<0.001$ & 0.438 & 0.703 \\
\hline Jejunum & 7.51 & 6.95 & 0.67 & & 0.418 & \\
\hline Ileum & 2.33 & 2.02 & 0.58 & & 0.609 & \\
\hline Colon & 5.87 & 5.95 & 0.44 & & 0.853 & \\
\hline
\end{tabular}

${ }^{1} \mathrm{CON}=$ nonsupplemented calves; $\mathrm{SCB}=$ calves supplemented with $S$. cerevisiae boulardii CNCM I-1079 at $10 \times 10^{9}$ cfu/d. Values are LSM.

${ }^{2} \mathrm{TRT}=$ dietary treatment.

${ }^{3} \operatorname{IgA}+=\mathrm{IgA}$-producing cells.

${ }^{4} \mathrm{Cq}=$ quantification cycle; $\Delta \mathrm{Cq}=\mathrm{Cq}(P I G R$ or $C D 79 A)-\mathrm{Cq}[(A C T B+G A P D H) / 2]$; lower $\Delta \mathrm{Cq}$ represents higher mRNA abundance level and vice versa.

Within the LP, plasma cells produce predominantly dimeric IgA that becomes actively transported across the gut epithelium into the lumen. The secretion of $\operatorname{IgA}$ is mediated by the polymeric immunoglobulin receptor (pIgR; Gutzeit et al., 2014). Following synthesis in epithelial cells, the pIgR is transported to the basolateral surface where it binds IgA and undergoes transcytosis. Having reached the apical surface, its extracellular, ligand-binding domain is cleaved off and released as the secretory component bound to $\operatorname{Ig} \mathrm{A}$, thus forming sIgA. In our study, the PIGR gene had greater expression in the jejunum and colon compared with the ileum, which is consistent with previous data reported by Liang et al. (2016) in calves. It was recently demonstrated in young calves that jejunal, but not ileal, PP was an immune induction site for pathogen-specific IgA antibody following a targeted enteric infection with Mycobacterium avium ssp. paratuberculosis (Facciuolo et al., 2016).

Table 4. Density of total bacteria and 4 bacterial groups in the gut digesta of 1-wk-old calves in response to the supplementation of Saccharomyces cerevisiae boulardii CNCM I-1079

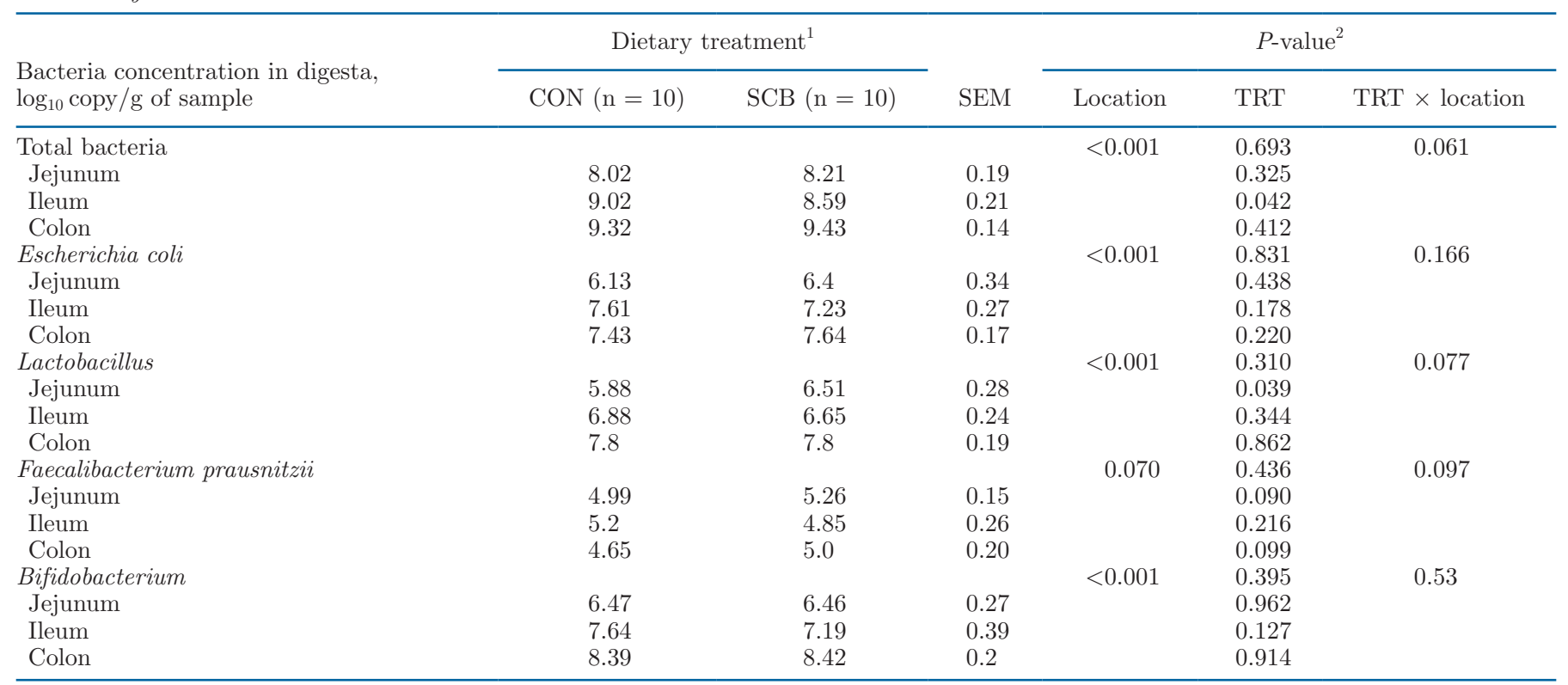

${ }^{1} \mathrm{CON}=$ nonsupplemented calves; SCB $=$ calves supplemented with $S$. cerevisiae boulardii $\mathrm{CNCM}$ I-1079 at $10 \times 10^{9} \mathrm{cfu} / \mathrm{d}$. Values are LSM.

${ }^{2} \mathrm{TRT}=$ dietary treatment 
Nevertheless, these data curiously conflict with the low sIgA concentration measured and the few detectable IgA+ plasma cells in the jejunum section. The proximal section of the jejunum containing discrete PP did not allow us to specifically target the PP area, which may be a source of explanation of the observed low activity of IgA production. In addition, if sIgA are produced in the jejunum section in response to a specific bacterial antigen, a basal supply of sIgA seems to be still continuously released in the ileum section. The infancy stage of IgA production at $1 \mathrm{wk}$ of age might also be specific and not reflected by the expression of genes involved in a mature IgA production system, as evidenced by the notably increased expression of PIGR from d 0 to $\mathrm{d} 7$ of age in newborn calves (Liang et al., 2016). Finally, pIgR transport occurs continuously and independently of binding of $\mathrm{Ig} A$, suggesting that a correlation between sIgA and its transporter may not exist (Phalipon and Corthésy, 2003). To highlight the precise effect of SCB on IgA production, the study would have benefited from establishing the antigen-specificity of the $\operatorname{sg} \mathrm{A}$ released in the lumen at this age.

Although S. boulardii induced both a local and systemic increase in total antibodies in healthy uninflamed intestine of mice, the degree to which $S$. boulardii contacted and influenced the host mucosal immune system was limited and did not induce antibodies reactive against yeast antigens themselves (Hudson et al., 2016). In accordance to our results, there was only minimal response induced in B-cell populations, but IgA secreting cells showed consistent trends toward increased numbers in supplemented mice, even if not statistically significant, with healthy intestines. Similarly, Rodrigues et al. (2000) demonstrated that with gnotobiotic animals, $S$. boulardii did not alter the development of PP (location of the precursors of IgA+ plasma cells), but rather induced an increase in the activity of plasmocytes preexisting in the LP, inducing an augmentation in the synthesis of $\operatorname{sIgA}$. In mice challenged with Clostridium toxin A, Qamar et al. (2001) demonstrated that S. boulardii induced a specific IgA immune response to toxin A when both are coadministered. The relative increase in specific $\operatorname{Ig} \mathrm{A}$ anti-toxin A production is greater than the observed increase in total IgA levels, suggesting that $S$. boulardii may act as a mucosal adjuvant. In our study, even if the 1-wk-old calves were healthy, the early stage of development of the intestine may have conferred a different interaction between $S$. boulardii and the host intestine. Evidence from studies suggest that $S$. cerevisiae interacts with pattern recognition receptors - including Toll-like receptors, nucleotide-binding oligomerization-like receptors, adhesion molecules, and lectins - which in turn direct the modulation of key signaling pathways, such as MAPK and NF- $\mathrm{BB}$ (Sou- gioultzis et al., 2006; Zanello et al., 2009). In addition, it seems that the ability to stimulate the production of sIgA in gnotobiotic mice was not the same for different commensal gut microorganisms (Moreau et al., 1982). Several bacterial genera belonging to both phyla Firmicutes and Bacteroidetes that may regulate sIgA have been identified in fecal samples of pigs; furthermore, animals specifically pertaining to Prevotella cluster had higher capacities to synthetize luminal sIgA (Mach et al., 2015). Nevertheless, more research is needed to elucidate if these modes of action play a role in the specific mechanism of sIgA release in the gut of newborn calves. The long-term effect on IgA production should also be investigated with SCB supplementation, but potential confounding factors due to onset of diseases in older calves could prove challenging to control.

The total load of bacteria in the ileum digesta was significantly lower in calves supplemented with SCB. Knowing that IgA's main mode of action is relative to the clearance of non-self-microorganisms from the intestinal lumen (Pabst et al., 2016), we speculate that potential pathogenic bacteria were complexed by $\operatorname{sIgA}$ in the lumen. Therefore, sIgA interferes with the ability of bacteria to adhere to and penetrate the mucosa, inhibiting their motility by facilitating entrapment in the mucus and then enhancing their clearance by peristalsis (Renegar et al., 1998), a phenomenon called "immune exclusion" (Brandtzaeg, 2003). Studies using mouse and rabbit models have reported the capacity of sIgA to entrap bacterial pathogens in the mucus layer overlying respiratory and intestinal epithelium in vivo (Boullier et al., 2009). It was also demonstrated that specific sIgA can bind to newly synthesized viral proteins inside the epithelial cells, preventing virion assembly and neutralizing viral replication (Mazanec et al., 1995). Although the capacity of specific sIgA to entrap pathogenic microorganisms in experimental in vitro settings is well documented, it has yet to be determined to what, if any, extent sIgA promotes immune exclusion of commensal bacteria in the ileum of calves. In addition to its function in immune exclusion, sIgA is thought to modulate initial exposure and educate the newborn's immature mucosal immune system by coating gut commensal bacteria (Macpherson and Slack, 2007). The postnatal colonization of the gastrointestinal tract with commensals provides bacterial stimuli that are crucial to the functional development and homeostasis of the major compartments of the gut-associated lymphoid tissue (Blümer et al., 2007). The relationship between intestinal microorganisms and SIgA led us to postulate that supplementation with SCB, in cooperation with sIgA, could enhance communication with the epithelial cell interface. For example, using human intestinal epithelial Caco-2 cells, grown as polarized monolayers, 
Mathias et al. (2010) found that associations between Lactobacillus or Bifidobacterium with nonspecific sIgA enhanced the probiotic's adhesion by a factor of 3.4fold or more. Moreover, binding of nonspecific $\operatorname{sIg} \mathrm{A}$ to bacteria potentiates their effects on selected events associated with adhesion, epithelial permeability, and signaling events. The higher concentration and proportion of Lactobacillus and F. prausnitzii in the jejunum of SCB calves could have resulted from improved anaerobic conditions due to SCB oxygen consumption or due to a higher coating of these commensal groups by elevated $\operatorname{sIg} \mathrm{A}$ in the lumen. It is nevertheless important to report that not all features examined in Mathias et al. (2010) were intended to change the communication with epithelial monolayer, highlighting an area of future study to better understand the complexity of interactions that ultimately lead to gut and mucus adhesion (MacKenzie et al., 2009).

\section{CONCLUSIONS}

A key factor in the health and growth of young animals is proper management during the newborn stage. This study demonstrated that 1-wk-old calves are already capable of developing immunity and that supplementation from birth with live $S$. cerevisiae boulardii $\mathrm{CNCM}$ I-1079 could help enhance immune function. Specially, we demonstrated that calves were able to produce and release endogenous sIgA in the gut, with larger concentrations found in the ileum and colon compared with the distal jejunum, and IgA+ plasma cell numbers were primed in the ileum. Importantly, early supplementation of SCB directly within colostrum did not impair immunoglobulin absorption. Moreover, it exerted a potential immunoprotective effect against pathogen infection and established intestinal homeostasis of the gastrointestinal tract by - at least in part - stimulating intestinal production and release of endogenous $\operatorname{sIgA}$ and enriching beneficial bacteria. The potential to improve sIgA intake from colostrum during the first days of life, and throughout maternal supplementation, also requires more attention. The growing pressure to limit the use of prophylactic antimicrobials has encouraged multidisciplinary approaches to improve gut health in calves and enhance options available to the dairy industry. Further research is required to investigate the long-term effects of SCB supplementation on sIgA later in life.

\section{ACKNOWLEDGMENTS}

We thank the team, including André Luis Nagatani Rigueiro, for their dedicated time during this newborn experiment and for their contributions to this research.
We also thank the staff of the Dairy Research and Technology Centre (University of Alberta, Edmonton, $\mathrm{AB}$ ) for their assistance with the animal experiment, Amanda Fischer for the revision of the manuscript, as well as Jan Shivers from University of Minnesota (Minneapolis, MN) for her technical assistance. This study was supported by funding from Lallemand Health Solution (Mirabel, QC), Alberta Milk (Edmonton, AB), the Saskatoon Colostrum Co. Ltd. (Saskatoon, SK) and the Natural Sciences and Engineering Research Council of Canada (Ottawa, ON). Clothilde Villot was supported by a Mitacs Accelerate Program from Mitacs Canada (Toronto, ON) and Lallemand (Blagnac, France). The authors have not stated any conflicts of interest.

\section{REFERENCES}

Allen, W. D., and P. Porter. 1975. Localization of immunoglobulins in intestinal mucosa and the production of secretory antibodies in response to intraluminal administration of bacterial antigens in the preruminant calf. Clin. Exp. Immunol. 21:407-418.

Baccili, C. C., S. M. N. F. de Oliveira, J. F. R. Costa, C. O. Massoco, C. R. Pozzi, and V. Gomes. 2018. Hematological and immunological development from birth to six months of age in Holstein calves. Arq. Bras. Med. Vet. Zootec. 70:1823-1832. https://doi.org/10 $.1590 / 1678-4162-9416$.

Blümer, N., P. I. Pfefferle, and H. Renz. 2007. Development of mucosal immune function in the intrauterine and early postnatal environment. Curr. Opin. Gastroenterol. 23:655-660. https://doi.org/10 .1097/MOG.0b013e3282eeb428.

Boullier, S., M. Tanguy, K. A. Kadaoui, C. Caubet, P. Sansonetti, B. Corthésy, and A. Phalipon. 2009. Secretory IgA-mediated neutralization of Shigella flexneri prevents intestinal tissue destruction by down-regulating inflammatory circuits. J. Immunol. 183:58795885. https://doi.org/10.4049/jimmunol.0901838.

Brandtzaeg, P. 2003. Role of secretory antibodies in the defence against infections. Int. J. Med. Microbiol. 293:3-15. https://doi .org/10.1078/1438-4221-00241.

Buts, J.-P., P. Bernasconi, J.-P. Vaerman, and C. Dive. 1990. Stimulation of secretory IgA and secretory component of immunoglobulins in small intestine of rats treated with Saccharomyces boulardii Dig. Dis. Sci. 35:251-256. https://doi.org/10.1007/BF01536771.

Charavaryamath, C., P. Fries, S. Gomis, C. Bell, K. Doig, L. L. Guan, A. Potter, S. Napper, and P. J. Griebel. 2011. Mucosal changes in a long-term bovine intestinal segment model following removal of ingesta and microflora. Gut Microbes 2:134-144. https://doi.org/ 10.4161/gmic.2.3.16483.

Chase, C. C., D. J. Hurley, and A. J. Reber. 2008. Neonatal immune development in the calf and its impact on vaccine response. Vet. Clin. North Am. Food Anim. Pract. 24:87-104. https://doi.org/10 .1016/j.cvfa.2007.11.001.

Choi, C. H., S. Y. Jo, H. J. Park, S. K. Chang, J.-S. Byeon, and S.J. Myung. 2011. A randomized, double-blind, placebo-controlled multicenter trial of Saccharomyces boulardii in irritable bowel syndrome: Effect on quality of life. J. Clin. Gastroenterol. 45:679-683. https://doi.org/10.1097/MCG.0b013e318204593e.

Cleusix, V., C. Lacroix, G. Dasen, M. Leo, and G. Le Blay. 2010. Comparative study of a new quantitative real-time PCR targeting the xylulose-5-phosphate/fructose-6-phosphate phosphoketolase bifidobacterial gene (xfp) in faecal samples with two fluorescence in situ hybridization methods. J. Appl. Microbiol. 108:181-193. https://doi.org/10.1111/j.1365-2672.2009.04408.x.

DeFranco, A. L. 1993. Structure and function of the B cell antigen receptor. Annu. Rev. Cell Biol. 9:377-410. https://doi.org/10.1146/ annurev.cb.09.110193.002113. 
Delroisse, J.-M., A.-L. Boulvin, I. Parmentier, R. D. Dauphin, M. Vandenbol, and D. Portetelle. 2008. Quantification of Bifidobacterium spp. and Lactobacillus spp. in rat fecal samples by real-time PCR. Microbiol. Res. 163:663-670. https://doi.org/10.1016/j.micres 2006.09.004

Doron, S. I., P. L. Hibberd, and S. L. Gorbach. 2008. Probiotics for prevention of antibiotic-associated diarrhea. J. Clin. Gastroenterol. 42(Suppl. 2):S58-S63. https://doi.org/10.1097/MCG $.0 \mathrm{~b} 013 \mathrm{e} 3181618 \mathrm{ab7}$.

Facciuolo, A., P. Gonzalez-Cano, S. Napper, P. J. Griebel, and L. M. Mutharia. 2016. Marked differences in mucosal immune responses induced in ileal versus jejunal Peyer's patches to Mycobacterium avium ssp. paratuberculosis secreted proteins following targeted enteric infection in young calves. PLoS One 11:e0158747. https://doi .org/10.1371/journal.pone.0158747.

Famulener, L. 1912. On the transmission of immunity from mother to offspring: A study upon serum hemolysins in goats. J. Infect. Dis. 10:332-368. https://doi.org/10.1093/infdis/10.3.332.

Fries, P. N., Y. I. Popowych, L. L. Guan, and P. J. Griebel . 2011. Agerelated changes in the distribution and frequency of myeloid and $\mathrm{T}$ cell populations in the small intestine of calves. Cell. Immunol. 271:428-437. https://doi.org/10.1016/j.cellimm.2011.08.012.

Furman-Fratczak, K., A. Rzasa, and T. Stefaniak. 2011. The influence of colostral immunoglobulin concentration in heifer calves' serum on their health and growth. J. Dairy Sci. 94:5536-5543. https:// doi.org/10.3168/jds.2010-3253.

Gutzeit, C., G. Magri, and A. Cerutti. 2014. Intestinal IgA production and its role in host-microbe interaction. Immunol. Rev. 260:76-85. https://doi.org/10.1111/imr.12189.

Hudson, L. E., C. D. McDermott, T. P. Stewart, W. H. Hudson, D. Rios, M. B. Fasken, A. H. Corbett, and T. J. Lamb. 2016. Characterization of the probiotic yeast Saccharomyces boulardii in the healthy mucosal immune system. PLoS One 11:e0153351. https:// doi.org/10.1371/journal.pone.0153351.

Husband, A. J., and A. Lascelles. 1975. Antibody responses to neonatal immunisation in calves. Res. Vet. Sci. 18:201-207. https://doi .org/10.1016/S0034-5288(18)33614-2.

James, R. E., and C. Polan. 1978. Effect of orally administered duodenal fluid on serum proteins in neonatal calves. J. Dairy Sci. 61:1444-1449. https://doi.org/10.3168/jds.S0022-0302(78)83747 -3 .

Johansen, F.-E., M. Pekna, I. N. Norderhaug, B. Haneberg, M. A. Hietala, P. Krajci, C. Betsholtz, and P. Brandtzaeg. 1999. Absence of epithelial immunoglobulin a transport, with increased mucosal leakiness, in polymeric immunoglobulin receptor/secretory component-deficient mice. J. Exp. Med. 190:915-922. https://doi.org/10 $.1084 / \mathrm{jem} .190 .7 .915$.

Li, X.-R., B. Du, H.-X. Fu, R.-F. Wang, J.-H. Shi, Y. Wang, M. S. Jetten, and Z.-X. Quan. 2009. The bacterial diversity in an anaerobic ammonium-oxidizing (anammox) reactor community. Syst. Appl. Microbiol. 32:278-289. https://doi.org/10.1016/j.syapm .2009.03.002.

Liang, G., N. Malmuthuge, H. Bao, P. Stothard, P. J. Griebel, and L. L. Guan. 2016. Transcriptome analysis reveals regional and temporal differences in mucosal immune system development in the small intestine of neonatal calves. BMC Genomics 17:602-618. https://doi.org/10.1186/s12864-016-2957-y.

Liebler, E. M., C. Küsters, and J. Pohlenz. 1996. Experimental mucosal disease in cattle: Changes in the number of lymphocytes and plasma cells in the mucosa of the small and large intestine. Vet. Immunol. Immunopathol. 55:93-105. https://doi.org/10.1016/ S0165-2427(96)05715-7.

Logan, E. F., W. Penhale, and R. Jones. 1973. Changes in the serum immunoglobulin levels of colostrum-fed calves during the first 12 weeks postpartum. Res. Vet. Sci. 14:394-397. https://doi.org/10 .1016/S0034-5288(18)33897-9.

Mach, N., M. Berri, J. Estellé, F. Levenez, G. Lemonnier, C. Denis, J. J. Leplat, C. Chevaleyre, Y. Billon, J. Doré, C. Rogel-Gaillard, and P. Lepage. 2015. Early-life establishment of the swine gut microbiome and impact on host phenotypes. Environ. Microbiol. Rep. 7:554-569. https://doi.org/10.1111/1758-2229.12285.
MacKenzie, D. A., L. E. Tailford, A. M. Hemmings, and N. Juge. 2009. Crystal structure of a mucus-binding protein repeat reveals an unexpected functional immunoglobulin binding activity. J. Biol. Chem. 284:32444-32453. https://doi.org/10.1074/jbc.M109 .040907 .

Macpherson, A. J., and E. Slack. 2007. The functional interactions of commensal bacteria with intestinal secretory IgA. Curr. Opin. Gastroenterol. 23:673-678. https://doi.org/10.1097/MOG .0b013e3282f0d012.

Malmuthuge, N., Y. Chen, G. Liang, L. A. Goonewardene, and L. L. Guan. 2015. Heat-treated colostrum feeding promotes beneficial bacteria colonization in the small intestine of neonatal calves. J. Dairy Sci. 98:8044-8053. https://doi.org/10.3168/jds.2015-9607.

Mantis, N. J., N. Rol, and B. Corthésy. 2011. Secretory IgA's complex roles in immunity and mucosal homeostasis in the gut. Mucosal Immunol. 4:603-611. https://doi.org/10.1038/mi.2011.41.

Mathias, A., M. Duc, L. Favre, J. Benyacoub, S. Blum, and B. Corthésy. 2010. Potentiation of polarized intestinal Caco-2 cell responsiveness to probiotics complexed with secretory IgA. J. Biol. Chem. 285:33906-33913. https://doi.org/10.1074/jbc.M110.135111.

Mazanec, M. B., C. L. Coudret, and D. R. Fletcher. 1995. Intracellular neutralization of influenza virus by immunoglobulin A anti-hemagglutinin monoclonal antibodies. J. Virol. 69:1339-1343. https:// doi.org/10.1128/JVI.69.2.1339-1343.1995.

McFarland, L. V. 2010. Systematic review and meta-analysis of Saccharomyces boulardii in adult patients. World J. Gastroenterol. 16:2202-2222. https://doi.org/10.3748/wjg.v16.i18.2202.

McFarland, L. V., C. T. Evans, and E. J. Goldstein. 2018. Strainspecificity and disease-specificity of probiotic efficacy: A systematic review and meta-analysis. Front. Med. 5:124. https://doi.org/ 10.3389/fmed.2018.00124.

Moreau, M. C., P. Raibaud, and M. Muller. 1982. Relation entre le développement du système immunitaire intestinal à $\operatorname{IgA}$ et l'établissement de la flore microbienne dans le tube digestif du souriceau holoxénique. Ann. Immunol. (Paris) 133D:29-39.

NAHMS. 2014. Health and Management Practices on US Dairy Operations, 2014. Accessed Jun. 2020. https://www.aphis.usda.gov/ animal_health/nahms/dairy/downloads/dairy14/Dairy14_dr _PartIII.pdf.

Owens, I. P., and K. Wilson. 1999. Immunocompetence: A neglected life history trait or conspicuous red herring? Trends Ecol. Evol. 14:170-172. https://doi.org/10.1016/S0169-5347(98)01580-8.

Pabst, O., V. Cerovic, and M. Hornef. 2016. Secretory IgA in the coordination of establishment and maintenance of the microbiota. Trends Immunol. 37:287-296. https://doi.org/10.1016/j.it.2016.03 .002 .

Phalipon, A., and B. Corthésy. 2003. Novel functions of the polymeric Ig receptor: Well beyond transport of immunoglobulins. Trends Immunol. 24:55-58. https://doi.org/10.1016/S1471-4906(02)00031 -5 .

Qamar, A., S. Aboudola, M. Warny, P. Michetti, C. Pothoulakis, J. T. LaMont, and C. P. Kelly. 2001. Saccharomyces boulardii stimulates intestinal immunoglobulin A immune response to clostridium difficiletoxin a in mice. Infect. Immun. 69:2762-2765. https://doi.org/ 10.1128/IAI.69.4.2762-2765.2001.

Quezada-Mendoza, V. C., A. Heinrichs, and C. Jones. 2011. The effects of a prebiotic supplement (Prebio Support) on fecal and salivary IgA in neonatal dairy calves. Livest. Sci. 142:222-228. https: //doi.org/10.1016/j.livsci.2011.07.015.

Rajput, I. R., L. Li, X. Xin, B. Wu, Z. Juan, Z. Cui, D. Yu, and W. Li. 2013. Effect of Saccharomyces boulardii and Bacillus subtilis B10 on intestinal ultrastructure modulation and mucosal immunity development mechanism in broiler chickens. Poult. Sci. 92:956-965. https://doi.org/10.3382/ps.2012-02845.

Renaud, D., D. Shock, S. Roche, M. Steele, E. Chevaux, and A. Skidmore. 2019. Evaluation of Saccharomyces cerevisiae boulardii CNCM I-1079 fed before weaning on health and growth of male dairy calves. Appl. Anim. Sci. 35:570-576. https://doi.org/ 10.15232/aas.2019-01889. 
Renegar, K. B., G. D. Jackson, and J. Mestecky. 1998. In vitro comparison of the biologic activities of monoclonal monomeric $\operatorname{IgA}$ polymeric IgA, and secretory IgA. J. Immunol. 160:1219-1223.

Reth, M. 1992. Antigen receptors on B lymphocytes. Annu. Rev. Immunol. 10:97-121. https://doi.org/10.1146/annurev.iy.10.040192 .000525 .

Rodrigues, A. C. P., D. Cara, S. Fretez, F. Cunha, E. Vieira, J. Nicoli, and L. Vieira. 2000. Saccharomyces boulardii stimulates SIgA production and the phagocytic system of gnotobiotic mice. J. Appl. Microbiol. 89:404-414. https://doi.org/10.1046/j.1365-2672.2000 .01128.x.

Roodposhti, P. M., and N. Dabiri. 2012. Effects of probiotic and prebiotic on average daily gain, fecal shedding of Escherichia coli, and immune system status in newborn female calves. Asian-Australas. J. Anim. Sci. 25:1255-1261. https://doi.org/10.5713/ajas.2011 .11312

Sabat, A. J., A. Budimir, D. Nashev, R. Sá-Leão, J. M. van Dijl, F. Laurent, H. Grundmann, and A. Friedrich; on behalf of the ESCMID Study Group of Epidemiological Markers. 2013. Overview of molecular typing methods for outbreak detection and epidemiological surveillance. Euro Surveill. 18:20380-20394. https://doi .org/10.2807/ese.18.04.20380-en.

Schneider, C. A., W. S. Rasband, and K. W. Eliceiri. 2012. NIH Image to ImageJ: 25 years of image analysis. Nat. Methods 9:671-675. https://doi.org/10.1038/nmeth.2089.

Shivley, C. B., J. Lombard, N. Urie, D. Haines, R. Sargent, C. Kopral, T. Earleywine, J. Olson, and F. Garry. 2018. Preweaned heifer management on US dairy operations: Part II. Factors associated with colostrum quality and passive transfer status of dairy heifer calves. J. Dairy Sci. 101:9185-9198. https://doi.org/10.3168/jds .2017-14008.

Snoeck, V., I. R. Peters, and E. Cox. 2006. The IgA system: A comparison of structure and function in different species. Vet. Res. 37:455-467. https://doi.org/10.1051/vetres:2006010.

Sougioultzis, S., S. Simeonidis, K. R. Bhaskar, X. Chen, P. M. Anton, S. Keates, C. Pothoulakis, and C. P. Kelly. 2006. Saccharomyces boulardii produces a soluble anti-inflammatory factor that inhib-

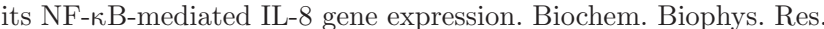
Commun. 343:69-76. https://doi.org/10.1016/j.bbrc.2006.02.080.

Stelwagen, K., E. Carpenter, B. Haigh, A. Hodgkinson, and T. Wheeler. 2009. Immune components of bovine colostrum and milk. J. Anim. Sci. 87(Suppl. 13):3-9. https://doi.org/10.2527/jas.2008 -1377 .

Stevenson, D. M., and P. J. Weimer. 2007. Dominance of Prevotella and low abundance of classical ruminal bacterial species in the bovine rumen revealed by relative quantification real-time PCR. Appl. Microbiol. Biotechnol. 75:165-174. https://doi.org/10.1007/ s00253-006-0802-y.

Strugnell, R. A., and O. L. Wijburg. 2010. The role of secretory antibodies in infection immunity. Nat. Rev. Microbiol. 8:656-667. https://doi.org/10.1038/nrmicro2384.
Vandesompele, J., K. De Preter, F. Pattyn, B. Poppe, N. Van Roy, A. De Paepe, and F. Speleman. 2002. Accurate normalization of real-time quantitative RT-PCR data by geometric averaging of multiple internal control genes. Genome biology 3:research0034. https://doi.org/10.1186/gb-2002-3-7-research0034.

Villot, C., T. Ma, D. Renaud, M. Ghaffari, D. Gibson, A. Skidmore, E. Chevaux, L. Guan, and M. Steele. 2019. Saccharomyces cerevisiae boulardii CNCM I-1079 affects health, growth, and fecal microbiota in milk-fed veal calves. J. Dairy Sci. 102:7011-7025. https:// doi.org/10.3168/jds.2018-16149.

Vital, M., C. R. Penton, Q. Wang, V. B. Young, D. A. Antonopoulos, M. L. Sogin, H. G. Morrison, L. Raffals, E. B. Chang, G. B. Huffnagle, T. M. Schmidt, J. R. Cole, and J. M. Tiedje. 2013 A gene-targeted approach to investigate the intestinal butyrateproducing bacterial community. Microbiome 1:8. https://doi.org/ 10.1186/2049-2618-1-8.

Wilson, R. A., A. Zolnai, P. Rudas, and L. V. Frenyo. 1996. T-cell subsets in blood and lymphoid tissues obtained from fetal calves, maturing calves, and adult bovine. Vet. Immunol. Immunopathol. 53:49-60. https://doi.org/10.1016/0165-2427(95)05543-6.

Yasuda, M., M. Fujino, T. Nasu, and T. Murakami. 2004. Histological studies on the ontogeny of bovine gut-associated lymphoid tissue: Appearance of $\mathrm{T}$ cells and development of $\mathrm{IgG}+$ and $\mathrm{IgA}+$ cells in lymphoid follicles. Dev. Comp. Immunol. 28:357-369. https://do .org/10.1016/j.dci.2003.09.013.

Yu, Z., and M. Morrison. 2004. Improved extraction of PCR-quality community DNA from digesta and fecal samples. Biotechniques 36:808-812. https://doi.org/10.2144/04365ST04.

Zanello, G., F. Meurens, M. Berri, and H. Salmon. 2009. Saccharomyces boulardii effects on gastrointestinal diseases. Curr. Issues Mol. Biol. 11:47-58.

Zoldan, K., J. Schneider, T. Moellmer, C. Fueldner, J. Knauer, M. Fuerll, A. Starke, M. Specht, K. Reiche, and J. Hackermueller 2017. Discovery and validation of immunological biomarkers in milk for health monitoring of dairy cows - Results from a multiomics approach. J. Adv. Dairy Res. 5:182.

\section{ORCIDS}

C. Villot (ㅇ https://orcid.org/0000-0001-8955-3733

K. Pedgerachny (i) https://orcid.org/0000-0001-9923-1287

F. Chaucheyras-Durand (® https://orcid.org/0000-0002-2125-438X

E. Chevaux (ํ) https://orcid.org/0000-0002-2375-5487

A. Skidmore (1) https://orcid.org/0000-0002-0547-5393

L. L. Guan ๑ https://orcid.org/0000-0002-8420-4371

M. A. Steele $\odot$ https://orcid.org/0000-0001-6941-6205 